AperTO - Archivio Istituzionale Open Access dell'Università di Torino

\title{
Copyright and truth
}

\section{This is the author's manuscript}

Original Citation:

Availability:

This version is available http://hdl.handle.net/2318/1841386

since 2022-02-16T17:34:02Z

Published version:

DOI:10.2202/1565-3404.1261

Terms of use:

Open Access

Anyone can freely access the full text of works made available as "Open Access". Works made available under a Creative Commons license can be used according to the terms and conditions of said license. Use of all other works requires consent of the right holder (author or publisher) if not exempted from copyright protection by the applicable law. 


\title{
Copyright and Truth
}

\begin{abstract}
Maurizio Borghi*
This Article calls into question the primary meaning of copyright law. It argues that copyright is not primarily a legal instrument, but rather a fundamental mode of human existence. The starting point of the analysis is Kant's definition of a book as a "public address" and of author's rights as ultimately being grounded in the furtherance and maintenance of truth. Building on Kant's argument, the Article defines the copyright primary subject matter as the act of speaking publicly in one's own name, and the copyright sphere as the author-public coalescence that such act of speaking generates. This enables reaching a proper understanding of the scope of copyright and to characterizing its specificity as compared to its "fellow rights," patents and trademarks.
\end{abstract}

\section{INTRODUCTION}

Copyright is often represented as a tool for regulating an intrinsically conflicting field. In the "copyright arena," so runs the account in the current discourse, multiple actors struggle to adjudicate as much control as possible over valuable resources such as information, knowledge or, briefly, culture. As a consequence, copyright is seen as a means of "striking a balance" between a potentially fatal clash of interests - broadly, the interests of "the owners" versus those of "the users," or, in more classical terms, the interests of the author as opposed to those of the public at large. ${ }^{1}$

* Law Lecturer at Brunel University, West London. Earlier versions of this Article have been presented at the conference on Copyright Culture, Copyright History, held by the Cegla Center at Tel Aviv University, January 2010, and at the Centre for Innovation Law and Policy at the University of Toronto, March 2010. The author is grateful to Michael Birnhack, Abraham Drassinower and Ariel Katz for their kind support and to all the participants at both events for helpful comments and discussion. Special thanks go to Paul Edward Geller for his invaluable insights.

1 For a thorough critique of the notion of "balance," see Abraham Drassinower, From Distribution to Dialogue: Remarks on the Concept of Balance in Copyright Law, 34 J. CORP. L. 991 (2009). 
We may call this view of copyright the clash-and-balance paradigm. ${ }^{2}$ Such a paradigm normally expresses itself in binary language: owners v. users, property v. commons, exclusivity v. public domain, etc. The most popular narrative attached to this paradigm is that of a "free culture" whose potential is threatened and diminished by the many barriers that the current copyright regime allows to be erected. In other words: copyright law, as it now stands, is no longer capable of performing its function of balance. ${ }^{3}$ The most relevant consequence of the predominance of this paradigm is that the copyright debate of recent years has been focused almost exclusively on the scope of copyright - more precisely, on how to limit the scope of author's rights of exclusion by increasing the weight of the opposite side of the scale in the balance. Little attention has been paid to what copyright itself is about, that is to its "what-about," as if, as Abraham Drassinower has rightly pointed out, the question of the subject matter of copyright was not the preliminary and most important one in this debate. ${ }^{4}$

It is not my intention to minimize the problems connected with an over-expanded copyright regime and its notorious downsides. The fact that copyright law has expanded over time is indisputable. ${ }^{5}$ Equally indisputable is the fact that the current copyright system is in crisis and it is increasingly being perceived as losing credibility and legitimacy. ${ }^{6}$ My question is whether the legitimate boundaries of copyright can be sufficiently determined through the lenses of the clash-and-balance paradigm, or whether a closer consideration of the "what- about" of copyright is needed for this purpose. Is such an

2 This paradigm underlies many of the current criticisms of the so-called neoclassicist economic approach to copyright, which justifies a broad proprietary regime over creative expression. For a critical review of both the neoclassicist approach and the criticisms thereof, see Neil Weinstock Netanel, Copyright and a Democratic Civil Society, 106 YAle L.J. 283, 306-40 (1996). See also, for a critique of the neoclassicist view of copyright as "incentive," Diane Leenheer Zimmerman, Copyrights as Incentives: Did We Just Imagine That?, 12 THEORETICAL INQUIRIES L. XXX (2011).

3 See, for example, almost anything written by Lawrence Lessig.

4 Drassinower, supra note 1, at 992-93 (arguing that subject matter issues are more important than scope issues when determining the public domain). On the importance of the subject matter issue compare also Brad Sherman, What Is a Work?, 12 THEORETICAL INQUIRIES L. XXX (2011).

5 Neil Weinstock Netanel, Why Has Copyright Expanded? Analysis and Critique, in 6 NEW DiRECTIONS In COPYRIGHT LAW 3 (Fiona Macmillan ed., 2008).

6 Paul Edward Geller, Beyond the Copyright Crisis: Principles for Change, 55 J. COPYRIGHT SOC'Y U.S.A. 165 (2008). 
investigation fated to be set aside as redundant in the face of the "obvious" consideration that copyright is just about balancing clashing interests?

As a matter of fact, some scholars have looked at copyright from perspectives that, albeit not always explicitly, call into question elements which cannot be simplistically reduced to interests in conflict. In various ways, these perspectives raise the awareness that copyright primarily, and not just secondarily, refers to a dimension that goes beyond any particular or even "general" interest. Copyright involves (as some have pointed out) matters such as democracy, a communicative sphere, or an ongoing dialogue between human beings. ${ }^{7}$ What all these different approaches have in common is that they overcome the binary language of the dominating paradigm and draw attention to $a$ third and higher instance which is at stake in copyright.

In this Article I argue that this third and higher instance, which is implicitly evoked by concepts like democracy, communication and dialogue, is better captured by upfront reference to truth. Kant's notion of an author's work as the act of speaking to the public, and the fundamental legal principles that arise from this elemental notion, represent the basis of my attempt to understand copyright as being grounded in the most fundamental need that human beings share when living in community with others, namely, the need for truth.

In Part I I consider Kant's argument on the wrongfulness of reprinting, with the aim of arriving at a suitable definition of copyright subject matter. In Part II I analyze the intimate link between the subject matter of copyright and truth, and clarify what truth is in this context. The reflection developed by Hannah Arendt in the essay Truth and Politics will be of guidance in my analysis. In Part III I attempt to outline the specificity of copyright by comparing its own way of relating to truth with that of other so-called intellectual property rights, namely patents and trademarks. I conclude with some provisional remarks on the legitimate scope of copyright.

7 See, e.g., Netanel, supra note 2 (pointing out that copyright is primarily about enhancing the democratic character of civil society); Michael D. Birnhack, More or Better? Shaping the Public Domain, in The Public Domain of Information 59 (Bernt Hugenholtz \& Lucie Guibault eds., 2005) (focusing on the copyright-public domain interplay as crucial in constructing a "communicative sphere"); Drassinower, supra note 1 (explicitly questioning the concept of "balance" and arguing that "dialogue" is a more appropriate metaphor to structure the interpretation of copyright law and its purpose). 


\section{Reconstructing the Subject Matter of Copyright: ACTIONS AND Not THINGS}

As is known, Kant's argument on the wrongfulness of unauthorized reprinting of books relies on the notion of a book as a speech to the public. ${ }^{8}$ In Kant's terms, a book is "a writing which represents a speech that someone, through visible signs of language, holds before the public." ${ }^{9}$ The one in the name of which the speech is delivered is the author, and the one who speaks in the name of the author is the publisher. The author, thus, speaks through the publisher to the public, and the publisher is entitled to act as intermediary between the author and the public only "in virtue of a mandate (mandatum) that the author gives to him to that effect."10 The unauthorized reprinter also speaks in the name of the author, but he does so without having a mandate to that effect. Nor can this permission to speak in the author's name

8 Kant addressed the issue of unauthorized reprint in the 1785 essay On the Unlawfulness of Book Reprinting. See Immanuel Kant, On the Unlawfulness of Reprinting (1875), reprinted in Primary Sources on Copyright (1450-1900) (Lionel Bently \& Martin Kretschmer eds., 2008), http://www.copyrighthistory.org (search "On the Unlawfulness of Reprinting"; then follow hyperlink) [hereinafter Kant, On the Unlawfulness of Reprinting]. The issue was then further addressed in the Doctrine of Right, published in 1797. See ImManuel Kant, Die Metaphysik der Sitten. Rechtslehre [The Metaphysics of Morals. Doctrine of Right], in 8 WERKAUSGABE IMMANUEL KANT 404 (Wilhelm Weischedel ed., 1968) [hereinafter Kant, Doctrine of Right] (discussion under heading "What Is a Book?"). The Kantian doctrine on book reprinting is mentioned in many leading commentaries of the nineteenth and twentieth centuries, both in Germany and in other countries, but only a few jurists have tried to develop it and, overall, it has had almost no influence on the dominating copyright discourse. See Friedemann Kawohl, Commentary on Kant's Essay On the Injustice of Reprinting Books (1785), in Primary Sources on Copyright (1450-1900), supra (search "On the Injustice of Reprinting"; then follow "commentary" hyperlink). The Kantian argument has been recently reconsidered in the light of the contemporary debate on copyright. See, in particular, Abraham Drassinower, A Rights-Based View of the Idea/Expression Dichotomy in Copyright Law, 16 CAN. J.L. \& JURISPRUDENCE 3 (2003); Abraham Drassinower, Authorship as Public Address: On the Specificity of Copyright vis-à-vis Patent and Trade-Mark, 1 Mich. ST. L. REV. 1999 (2008); Netanel, supra note 5, at 29-33; Leslie K. TreigerBar-Am, Kant on Copyright: Rights of Transformative Authorship, 25 CARDOZO ARTS \& ENT. L.J. 1059 (2008).

9 Kant, Doctrine of Right, supra note 8, at 404.

$10 I d$. at 404. Kant denotes the publisher as the one who "provides in his own name [nothing but] the mute instrument for the delivery of an author's speech to the public." Kant, On the Unlawfulness of Reprinting, supra note 8, at 407 (emphasis added). 
be deduced from the fact that, because the book has been published, one can legitimately possess a copy thereof: the mere possession of a thing can never entail a positive right to demand from a person (the author) that he is obliged to act in some way (speaking to the public). ${ }^{11}$ Therefore, the unauthorized reprinter speaks to the public either in virtue of an intrusion into another's business, or by presumptuously forcing someone to perform an act against his will. As a consequence he commits a twofold wrong: against the legitimate publisher, as he deprives him of the profits he could have derived from the execution of the author's mandate; and against the author himself - since he undertakes a business in his name (namely, speaking to the public) without and against his consent. ${ }^{12}$

Pivotal to Kant's argument is identifying the mandate as the contractual form which characterizes the dealings between the author and the publisher. What is, in essence, a mandatum? As an institution of Roman contract law, mandatum regulates the relationship between individuals as far as actions to be carried out - rather than things to be exchanged or works to be performed - are concerned..$^{13}$ In the traditional terminology it is a "perfect contract," in the sense that it is concluded in itself by the carrying out of the entrusted action, without the need to be completed by further deeds, such as an act of payment. ${ }^{14}$ The subject of this ideal contract between author and

11 Kant, On the Unlawfulness of Reprinting, supra note 8, at 407-08.

12 Copyright lawyers may regard such a twofold wrong as corresponding to the well known distinction between "economic" and "moral" rights. However, it is worth noting that, in Kant's argument, the alleged economic right is essentially a publisher's right that arises only as a consequence of the author's mandate, and it is very limited in scope: on the one hand, it does not extend to acts other than those necessary to deliver the author's own words, see infra note 20; on the other hand, it is not necessarily an exclusive right. As Kant puts it, the "right of publication" (i.e., reproduction and distribution) is an exclusive right only insofar as "the competition of others in his business would effectively render the conduct of [the author's mandate] impossible for him." Kant, On the Unlawfulness of Reprinting, supra note 8 , at 414-15. This means that the reason for the publication right being exclusive is purely contingent.

13 Mandatum is distinct from both locatio operarum (contract for work to be done) and emptio-venditio (purchase and sale). Cf. ADOLF BERGER, ENCYCLOPEDIC DiCTIONARY OF ROMAN LAW at 452, 567, 574 (1953) (entries Emptio venditio, Locatio conductio operarum and Mandatum).

14 Typically a mandatum is based on the trust (fides) of the two counterparts, and it may - but does not have to - be followed by a grateful reward in the form of an honorarium. The main characteristic of the honorarium compared to other forms of payment (such as the pretium and the merces, which correspond respectively to contracts of emptio-venditio and locatio operarum) is that it has no relationship of equivalence with the action entrusted. In other words, an entrusted 
publisher is not a "thing" (for instance, an "immaterial thing" such as a text as fixed in the manuscript to be reproduced in copies) or a "work" (such as an "intellectual work" performed by the author), but rather an action - namely, the act of speaking to the public in one's own name. ${ }^{15}$ What the publisher actually tells the public is the following: "Through me a writer is having this or that brought to your attention, for your information, etc. I answer for nothing, not even for the liberty which he is taking in speaking publicly through me; I am just the mediator of this reaching to you." 16

This notion of the subject matter of the author-publisher contract as an action deserves some further comments. In a way, it clashes with the common understanding of the work, as subject matter of copyright, as being primarily a good - be it immaterial, intangible, or even "spiritual." This common understanding is not entirely wrong. It is not wrong, in the sense that from a certain point of view such subject matter is comparable to any other good capable of being used as a means of exchange. In particular, a work in the form of book is prima facie akin to money: it circulates from hand to hand and serves as a universal means of exchange. As Kant himself puts it in the Doctrine of Right, money is the concept of the most powerful and useful means by which people reciprocally exchange "the fruits of their labor"; ${ }^{17}$ similarly, a book is the concept of "the greatest reciprocal exchange of thoughts." ${ }^{18}$ Yet if we look at these two means of exchange from a purely legal perspective, particularly from the perspective of the rights that can be contractually derived from their use, a landmark difference surfaces: money serves for any transfer of properties, insofar as by means of money any contract of purchase and sale (emptio-venditio) can be concluded. By contrast, a book can never serve a purchase-and-sale relationship. ${ }^{19}$ The

action cannot be "valued" as an exchangeable thing or a work done. Hence the difference between opus (work) and opera (act). Cf. BERGER, supra note 13, at 488, 581, 649 (entries Honorarium, Merces and Pretium). For a discussion of these relationships, see Maurizio Borghi, Rewarding Creativity: In Law, Economics and Literature, 1 ANCILLA IURIS 54 (2006).

15 Kant, On the Unlawfulness of Reprinting, supra note 8, at 407 n.? ("[T]he essential point that it is not a thing which is thereby delivered, but an act [opera], namely a speech, and, what is more, literally.").

16 Id. at 406

17 Kant, Doctrine of Right, supra note 8, at 401.

18 Id. at 400.

19 Apart from the purchase of copies thereof. Yet, as we have seen, possession of a copy does not trigger any right over the book itself - more precisely, over the action that the book entails. 
speech it represents "through visible signs of language" is not transferred as a form of property from an original owner to an intermediary and eventually to a purchaser, but is entrusted to the intermediary as a duty to be accomplished towards third parties, namely to the public. What is being transferred to the intermediary by this contract is nothing but a duty (and a faculty) to retell. ${ }^{20}$

The subject matter of the author-publisher transaction is therefore an action, and not a thing. Why does this difference matter? Because actions, unlike things, cannot be divorced from the aim and purpose they are directed to and for which they have been entrusted to others. Actions have necessarily a purpose or an end. ${ }^{21}$ By contrast, things can be regarded as having no "why" and end, and this, in principle, does not affect their legal significance. For example, a piece of land or a piece of information, as things, can be considered as objects of certain rights regardless of the purpose or end (if any) for which they have been transferred from one owner to another. The same is not generally valid for actions. Actions are in themselves inseparable from their own purpose or end, and this does affect the possibility of their being entrusted to others and the way in which they are entrusted.

If this is true, then the question arises regarding what is the end of an act such as speaking publicly in one's name. We are asking here for a presumptive end, namely an end which can be reasonably expected in

20 Retelling has here the literal sense of reiterating the speech in the author's own words by means of an appropriate instrument (a "mute instrument," see discussion supra note 10). This contract cannot extend to non-literal retelling, since a mandate to speak to the public in the author's name but in someone else's words would be contradictory. As Kant himself states, abridgements, translations and, generally, reworking of an author's work do not qualify as reprint, and are therefore permitted: "For here it is another author who is conducting through his publisher a different business to that of the first author, and this other author is therefore not encroaching in the latter's business with the public." Kant, On the Unlawfulness of Reprinting, supra note 8, at 417 (emphasis added); $c f$. Treiger-Bar-Am, supra note 8.

21 As Hannah Arendt puts it:

Action needs a deliberate planning ahead, for which Aristotle coins a new term, proairesis, choice in the sense of preference between alternatives one rather than another. . . The faculty of choice is necessary whenever men act for a purpose (heneka tinos), insofar as means have to be chosen, but the purpose itself, the ultimate end of the act for the sake of which it was embarked on in the first place, is not open to choice.

2 Hannah AREndt, The Life of THE Mind 60-61 (1978). As we shall see in the following, the purpose of the act of speaking publicly in one's own name is not open to choice, and this very fact makes possible the speakers' faculty of choice (or, in other words, their freedom of speech). 
advance, prior to any contingent embodiment of the act - that is, regardless of the contingent purpose of each individual act of speaking. Is there any such end?

\section{A. Action - To What End?}

In traditional copyright discourse, and particularly in that of continental Europe, the statement is often made that copyright ultimately serves to assure the author's autonomy in self- expression, or the author's liberty to express his own "personality" in writing or in any other material form. In this view, authors do primarily "express" themselves or their personality in their works. ${ }^{22}$ Accordingly, we could say that the presumptive end of any act of speaking publicly in one's own name is self-expression. But can we be satisfied with this assumption?

Not really. As a matter of fact, the idea of expressing oneself just highlights an outward trait of the said act. To be sure, every act of speaking is in a way "expressing," but this obvious consideration leaves completely unanswered the question why one's expressions should be addressed to and shared with others. It is at least questionable whether the idea of self-expression as such is of any guidance when dealing with issues touching on the very nature of authorship. ${ }^{23}$ As a matter of fact, even assuming that the author expresses

22 For a critique of this paradigm (and of the opposite "marketplace" paradigm as well), see Paul Edward Geller, Must Copyright Be For Ever Caught Between Marketplace and Authorship Norms?, in OF AUTHORS AND ORIGINS: ESSAYS IN COPYRIGHT LAW 159, 178-82 (Brad Sherman \& Alain Strowel eds., 1994) (discussion under heading "Do Authors Express Themselves?").

23 In a similar vein, but referring more generally to the common understating of works of art and of art as such as a "form of expression," Martin Heidegger observes that "the characterization of art as expression is not incorrect. Such a view is as undeniable as the sentence which says: motorcycle is an object which produces noise. Every technician would burst out laughing before such a definition of what this mechanical contrivance is. Yet nobody is laughing at the fact that, for very long time, we've been talking nonsense on art as 'expression.' "MARTIN HEIDEGGER, Vom Ursprung des Kunstwerkes. Erste Ausarbeitung [1931/32] [On the Origin of Work of Art. First Draft], in 5 HeIdegGer Studies 5, 17, (1989). For an example of such talking nonsense in legal discourse, see the text of the UNESCO Convention on Cultural Diversity, in particular its curious circular speaking: art. 1(a) "[The objective of this Convention is] to protect and promote the diversity of cultural expressions," and art. 4(1) (Definition of cultural diversity) "'Cultural diversity' refers to the manifold ways in which the cultures of groups and societies find expression." Convention on the Protection and Promotion of the Diversity of Cultural Expressions, arts. 1(a), 4(1), Oct. 20, 2005, available at http://unesdoc.unesco.org/images/0014/001429/142919e.pdf (emphases added). For 
himself publicly, it remains unclear why the public should have an interest in coming to know the author's self or personality. Therefore, the question remains: to what end does the author need to speak publicly?

As we shall see, Kant's philosophy is not elusive on this point. The following two subsections look more closely into this issue, by considering separately the two elements of the act which constitute the subject matter of the author-public relation mediated by the publisher, namely the act of speaking publicly in one's own name. The remaining part of the Article tries to draw some consequences from this reading.

\section{B. Speaking Publicly}

We have previously mentioned a difference between money, as a means to exchange goods, and books, as a means to exchange and circulate thoughts. We can now point out a further, more essential, difference between thoughts and goods in general, including so-called intangible goods. The relationship between thought and its public communication is not something extrinsic like that between goods and their circulation. A good, a commodity, remains the same regardless of whether it circulates or not. It can lie unemployed in a warehouse or stored in a database, and this does not alter its nature. By contrast, thoughts - contrary to what is commonly assumed - cannot be what they ought to be in the absence of communication. Thinking is somehow intrinsically public, and this in two senses: firstly, thinking itself has immediately to do with something in which all humankind is likely to have an interest, and it is never a private affair - even when the act of thinking is carried out privately or in solitude. Secondly, and consequently, thinking is not fully accomplished unless it is publicly communicated, that is to say until it is shared with other men. This last point is clearly addressed by Kant in a celebrated paragraph of the 1786 article What Does It Mean to Orient Oneself in Thinking?:

It is often said that a superior power can deprive us of the freedom to speak or to write, but not of the freedom to think. But how much and how correctly would we think, if we didn't think, so to say, "in common" with others, to whom we communicate our thoughts and who communicate theirs to us? Thus one can really say that the

a critical analysis, see Fiona Macmillan, Copyright, the World Trade Organization, and Cultural Self-Determination, in 6 NEW DIRECTIONS IN COPYRIGHT LAW, supra note 5 , at 307 . 
external power that deprives men of the freedom to communicate their thoughts publicly, also deprives them of their freedom to think, that is, the only treasure left us in the midst of social impositions, the only means which can still permit us to find remedies for the ills of our condition. ${ }^{24}$

A power which limits the freedom of communicating publicly also prejudices the possibility of thinking itself. Why is that so? It is because thinking is essentially, and not just afterwards or occasionally, thinking-incommon with others.

In Kantian terms, thinking means essentially judging. ${ }^{25}$ Judging, in turn, means connecting; namely connecting a predicate $(\mathrm{P})$ with a subject $(\mathrm{S})$ in a proposition (whose general form is: $S$ is $P$ ). Now, judging (connecting) is certainly an operation that each human being can perform individually. But precisely in this act of connecting, the human being necessarily relies on something external to himself, namely on the matter to which the proposition refers. In Kantian terms, every judgment is based on "the necessary unity," in view of which the judgment is carried out. ${ }^{26}$ In this sense, precisely in the individual act of judgment each individual is de-individualized — he goes beyond himself and heads towards something other. The most immediate form of this being-by-otherness is being with other human beings. This is why it is so necessary to have one's own thoughts (judgments) tested by other thinking (judging) beings.

Now, communication to others is a means - even though only subjective - of testing the correctness of one's own judgment (i.e., its accordance with the object) through its accordance with the others' judgments (which, if the judgment is correct, will also be in accordance with the same object):

For in this case [not the certainty, but] the presumption, at least, arises

24 Immanuel Kant, Was heißt, sich im Denken orientieren? [What Does It Mean, to Orient One's Self in Thinking?], in 5 WeRKaUsGabe IMMANUEL KANT, supra note 8 , at $267,280$.

$25 C f$. Immanuel Kant, Kritik der reinen Vernunft [Critique of Pure Reason], in 3 WERKAUSGABE IMMANUEL KANT, supra note 8, at A 59, B 84: "[W]e can reduce all acts of understanding to judgments, so that understanding may be represented as the faculty of judging. For it is, according to what has been said above, a faculty of thought." We cannot here question the scope and legitimacy of this understanding of thinking as judgment. For the sake of this analysis it is sufficient to observe that this understanding is intimately related to a corresponding understanding of truth as "correctness."

26 The concept of such unity is the "category." The ways of connecting, i.e., of unifying, are deduced from the traditional table of judgments. Id. at A 70, B 95. 
that the agreement of all judgments with each other, in spite of the different characters of the subjects, rests upon the common ground of the agreement of each with the object, and thus the correctness of the judgment is established. ${ }^{27}$

In the Anthropology Kant maintains the same principle, and he explicitly relates it to the freedom of the press:

It is so certain that we cannot give up this means [consisting in submitting one's own judgment to the others' intellect] to assure ourselves of the truth of our own judgment, that this is perhaps the principal reason why learned people fight so hard for the freedom of the press. If this freedom is denied, we would thereby lose a very potent means for proving the correctness of our own judgments and we would be left to error. ${ }^{28}$

The freedom of the press, that is the freedom of addressing one's own thoughts to the whole reading world: is an essential condition for thinking. Thinking, in turn, is the only way human beings have to be free from error, that is, to be in the truth.

We may conclude that the presumptive end of every act of speaking publicly is not an undetermined "self-expression" or the manifestation of one's own personality, ${ }^{29}$ but rather the furtherance and maintenance of truth.

Yet why does this act necessarily entail speaking in one's own name?

\section{Speaking in One's Own Name}

Speaking publicly is justified as it is the precondition for the full deployment of thinking, which in turn is the way in which humans can distinguish truth from error. But such speaking in public is also qualified as speaking in one's own name. This qualification is not accidental. It is truth itself that requires it. It is for truth's sake that each public address must be in one's own name. This point merits further attention.

The distinction between speaking in one's own name and speaking in someone or something else's name mirrors the distinction that Kant draws between "private" and "public" uses of reason:

27 KANT, supra note 25, at A 821-1, B 848-9.

28 IMMANUEL KANT, Anthropologie in pragmatischer Hinsicht [Anthropology from a Pragmatic Point of View], in 12 WeRKAUSGABE IMMANUEL KANT, supra note 8, at BA 7.

29 As T.S. Eliot puts it: "[A poem] is not the expression of personality, but an escape from personality." Geller, supra note 22, at 180 (quoting Eliot). 
By the public use of one's reason I mean the use which anyone may make of it as a man of learning before the whole reading world. Private use I call that which one may make of it in a particular civil post or office which is entrusted to him. ${ }^{30}$

As an example, a private use is that of a clergyman before his pupils, whereby he is bound to instruct them in catechism conforming to the doctrine of the church he serves. Similarly, we may say, a lecturer on copyright law is bound to instruct his or her students on how the statute law applies to the relevant cases. Both the lecturer and the clergymen, in those particular tasks that are entrusted to them, have a duty to instruct pupils and students on existing norms and doctrines and to educate them accordingly. They enjoy no freedom to revise and amend the respective doctrine at their will, since they do not speak in their own person, but in the name of the discipline they respectively serve. Yet both the clergymen and the lecturer, as men of learning, have not only the complete freedom, but also the duty, to impart to the public at large all their criticisms and thoughts on mistaken aspects (if any) of their respective doctrines. These two manners of making use of one's own reason can coexist, and normally do, but must never be confused with each other. ${ }^{31}$ It is only in the latter, the public use of reason that men enjoy unrestricted freedom to speak in their own person:

Thus an appointed teacher's use of his reason for the sake of his congregation is merely private, because, however large the congregation is, this use is always only domestic; in this regard, as a priest, he is not free and cannot be such because he is acting under instructions from someone else. By contrast, the cleric - as a man of learning who speaks through his writings to the public as such, i.e., the world at large - enjoys in this public use of reason an unrestricted freedom to use his own rational capacities and to speak his own person. ${ }^{32}$

30 Immanuel Kant, Beantwortung der Frage: Was ist Aufklärung? [Answer to the Question: What is Enlightenment?], in 11 WERKAUSGABE IMMANUEL KANT, supra note 8 , at 53, 55. For a discussion of the concept of public use of reason, see Maurizio Borghi, The Public Use of Reason: A Philosophical Understanding of Knowledge Sharing, 3 INT'L J. HumAN. 179 (2006).

31 An example of confusion between the private and public use of reason is when a lecturer uses his or her position to address ideological sermons to students. Another example is when a scholar covertly promotes some lobby's interests in a scientific article. Although the distinction between the private and public use of reason is (in theory) clear-cut, it fatally tends to become confused when it comes to practice.

32 Kant, supra note 30, at 56. 
The furtherance of truth requires that men not be bound by any externally entrusted obligations. The trait of publicity which characterizes this unrestricted and properly free use of reason is not purely empirical. In other words, a use of one's own reason does not qualify as public in virtue of the great number of people which may factually or potentially be reached by the speech. "Public" and "private" are here qualitative, not quantitative, concepts.

What singles out speaking in one's own name is primarily the freedom that the speaker takes in addressing his speech to the public. Any act of free speech is a speaking in one's own name, and vice versa. Once a word in one's own name is addressed to other men, it becomes eventually visible in its double status as the author's own word and as a word addressed to every single human being, namely addressed to all men who have an interest in it, and from then on it can start to be experienced as such.

\section{Reconstructing the Copyright Sphere: Truth AND COALESCENCE}

The subject matter of the contract between author and publisher is an act, namely the act of speaking publicly in the author's name. This act is presumptively aimed at the furtherance of truth. To be sure, an act of speaking can be aimed at ends that have nothing to do with truth, such as opinion as such, leisure or just entertainment. A speech can even be aimed at promoting untruth or deliberate falsehood. However, it is precisely against the background of this likelihood - namely, of being distracted by mere opinion or entertainment, or even being captured in untruth - that the furtherance of truth gains its clear stance. ${ }^{33}$ From this point of view, the freedom of speaking in one's own name includes the freedom of amending,

33 The fact that in copyright law any work has equal status independently from the "content" it delivers is metaphysically grounded in this relationship to truth. It is only in a utilitarian approach, where copyright is a means to incentivize "progress," that works may be considered differently according to their content. See Zimmermann, supra note 2 . 
denying and even invalidating anyone else's speech. ${ }^{34}$ This freedom can only be sufficiently determined for truth's sake.

It appears that the act of speaking publicly in one's own name cannot be comprehended as an isolated act of communication, but must be necessarily considered as designing a field - namely a filed in which nothing but truth itself is at stake. Yet what is truth?

\section{A. Rational Truth, Factual Truth, Reliance}

In this analysis we cannot afford a thorough investigation of the essence of truth and will therefore take the word initially in the sense in which it is commonly understood. Such a common understanding in turn depends on the traditional meaning of truth, a meaning that Kant himself shares. For Kant, as for all modern metaphysical thinking, truth is, formally, the agreement of one's judgment with the relevant object. "True" is a judgment which is in accordance with the facts or with reason; "false" is a judgment which is not in accordance with the facts or with reason. ${ }^{35}$ A corollary of this traditional understanding is that there is factual truth as distinguished from rational truth.

Although we cannot question here the scope and legitimacy of this understanding, we must place the issue in its appropriate context. To that end, we shall refer to the analysis developed by Hannah Arendt in her essay Truth and Politics. ${ }^{36}$

As Arendt puts it, examples of rational truths are "the three angles of a triangle should be equal to two angles of a square" or "it is better to suffer wrong than to do wrong"; an example of factual truth is "Germany invaded

34 This inalienable freedom justifies limitations to the scope of copyright, such as expressed by the doctrine of fair dealing for purposes of criticism or review, $c f$. Drassinower, supra note 1, at 1004-05, or resulting from the so-called idea/expression dichotomy, as firstly elaborated by Fichte in the 1793 essay Proof of the Unlawfulness of Reprinting. Johann Gottlieb Fichte, Proof of the Unlawfulness of Reprinting (1793), reprinted in Primary Sources on Copyright (1450-1900), supra note 8 (search "Proof of the Unlawfulness of Reprinting"; then follow hyperlink). For a detailed analysis of Fichte's argument, see Maurizio Borghi, Owning Form, Sharing Content: Natural-Right Copyright and Digital Environment, in 5 NEW DIRECTIONS IN COPYRIGHT LAW 197 (Fiona Macmillan ed., 2007).

35 KANT, supra note 25, at A 58, B 82; see also id. at A 489, B 517.

36 Hannah Arendt, Between Past and Future 223-59 (Penguin Books 2006) (1961). 
Belgium in 1914." ${ }^{37}$ Both rational and factual truths are distinguished, in turn, from opinion. ${ }^{38}$

Traditionally, the opposition between truth and opinion affects mainly the so-called rational truth. However, as Hannah Arendt acutely observes, facts and events are "infinitely more fragile things than axioms, discoveries, theories," since they belong to the ever- changing field of affairs of men, and once they have been removed from the shared memory - either as a consequence of negligence or as an effect of deliberate maneuver - "no rational effort will ever bring them back. ${ }^{139}$ Rational truth is permanently at risk of being downgraded to opinion, where it is likely to disappear in the ever-changing diversity of views, and this is the fate that it almost always suffers when it is exposed in the marketplace. However, this risk is even more insidious when it comes to factual truth. Facts are haphazard and their occurrence does not obey any rational necessity: they could always have occurred in other ways. Hence, paradoxically, they are even more subject than axioms and discoveries to being transformed into opinions and, once a factual truth has been discredited as "just another opinion," it can easily be stifled as such. A factual truth survives only insofar as it is witnessed and spoken about. It is "political by nature." 40

If that is true, then one might expect that the presumptive end of the act of speaking publicly in one's own name is more the furtherance and maintenance of factual truth than of rational truth. The latter does not necessarily need to be confirmed by the agreement of others and can be furthered in solitude. It is not political in nature. It does not need to be publicly addressed in order to be what it is. It may be communicated to others, but this act of communication does not affect or change its stance.

To be sure, rational truth is not affected by the agreement or disagreement of others. However, we cannot conclude on this ground that rational truth

37 Id. at 226. On the capacity of factual truths to survive the onslaught of untruth, in particular in the form of political lie, Hannah Arendt observes:

It is true, considerably more than the whims of historians would be needed to eliminate from the record the fact that on the night of August 4, 1914, German troops crossed the frontiers of Belgium; it would require no less than a power of monopoly over the entire civilized world. But such a power of monopoly is far from being inconceivable.

Id. at 235 .

38 Id. at 232.

39 Id. at 227.

$40 \quad I d$. at 234. 
can subsist independently of human togetherness. It is not affected by others' judgment - and nevertheless it is still essentially related to human togetherness as much as factual truth is. As Hannah Arendt clearly puts it:

Rational truth enlightens human understanding, and factual truth must inform opinions, but these truths, though they are never obscure, are not transparent either, and it is in their very nature to withstand further elucidation, as it is in the nature of light to withstand enlightenment. ${ }^{41}$

By the same token, Kant, when addressing the issue of freedom of the press ${ }^{42}$ warns against the belief that this means of proving the correctness of our own judgment can be easily waived when it comes to rational knowledge such as mathematics or philosophy. This is because, although "in philosophizing we do not need, and we should not need to appeal to the judgment of others to corroborate our own," ${ }^{43}$ the fact that a view which has been expounded publicly doesn't find support, may still be a symptom of error. And from this point of view mathematics itself "is not privileged at all," since if there was no "perception of the fact that the judgment of the land-surveyor regularly agreed with the judgment of all the others working diligently and carefully in the same domain, mathematics itself would not be able to be free from the fear of falling into error." 44

In Hannah Arendt's terms, rational truth needs elucidation as much as factual truth needs corroboration. Regardless of whether truth is "rational" or "factual," a human togetherness is necessarily implied in truth. This means that there is a trait which belongs to all manners by which truth is experienced by men, a trait that so-called factual and rational truth have in common. How can we characterize this trait? The words that Hannah Arendt uses in conclusion to her essay may provide a precious indication: "Conceptually, we may call truth what we cannot change; metaphorically, it is the ground on which we stand and the sky that stretches above us."45

Truth, as metaphorically ground and sky, is the element on which we, as human beings, ultimately rely. This trait of reliance is confirmed by the way in which the English language itself understands the word "truth." ${ }^{46}$ For

\footnotetext{
Id. at 238.

See supra text accompanying note 28.

KANT, supra note 28, at A 128-29.

Id. at A 129.

ARENDT, supra note 36, at 259.

46 "True" comes from the Old-English triewe or treowe, which means "faithful, trusty, trustworthy," perhaps ultimately from the Indo-European *dru- "tree," on the notion of "steadfast as an oak," and hence the notion of something to rest upon with assurance. Compare the entries for "True": True, in Online Etymology Dictionary
} 
instance, what we call "a true argument" is not primarily an argument which is factually or rationally correct, but an argument we can rely on. Similarly, a "true hammer" is not just a hammer which is non-imaginary and "real," but primarily a hammer we can trustfully rely on when hammering a nail to a wall or on a floorboard. A "true man" is someone on whose humanity we can rely. And so forth.

We may term the element that belongs to truth, as far as it is experienced by man in common with other men, reliance. Any human togetherness is tied, in one way or another, to truth as reliance. At the same time, truth as reliance needs human togetherness to be what it is. ${ }^{47}$

It is necessary now to find a suitable characterization of this element of togetherness which is essentially implied in truth as reliance.

\section{B. Coalescence}

The presumptive end of each act of speaking publicly in one's own name is the furtherance and maintenance (elucidation) of a trait which belongs to all manners by which truth is experienced by men, and that we have termed

(Douglas Harper ed., 2001), http://www.etymonline.com (search "True"; then follow hyperlink), and True, in OXFORD ENGLISH DICTIONARY (2d ed. 1989). This understanding of truth according to the English mother tongue shines outstandingly in the following poem of Emily Dickinson:

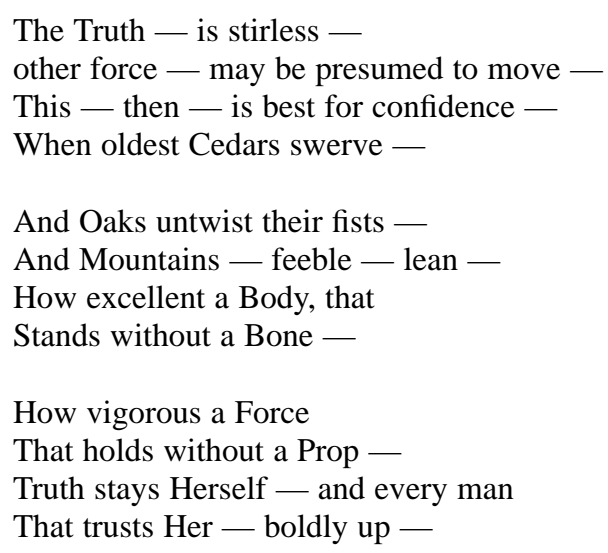

47 This constitutive link between truth and men is captured in the last two verses of Emily Dickinson's poem. DICKINSON, supra note 46. 
"reliance." This furtherance and maintenance requires freedom of speaking in one's own name and liberty of thinking in common with others.

Author and public are not just opposing parties to an act of communication. Nor do they simply engage in an exchange of informational values. Rather, author and public are coalescing parties to a common act of thinking. They coalesce to a common end: the common end of being in the truth.

If thinking is properly thinking in common, then the speaking in public of which the book is the mute instrument is not just a delivery of a self-made thought to a self-constituted audience. It is neither the act through which the author "expresses" his personality, nor the event owing to which the public may gain "access" to otherwise inaccessible thoughts. In all these understandings, speaking in public is represented as an exchange of (informational) values between two self-constituted poles: it becomes, paradoxically, a private connection between two poles, represented respectively by the "author" and the "public."48 Speaking in public is, rather, the act owing to which thinking reaches its full breadth and achievement as furtherance of truth. It is this latter, the furtherance of truth, that requires that author and public reach each other in what we may term a thinking coalescence. ${ }^{49}$

We can rephrase Kant's pivotal sentence about the freedom of the press, which has been quoted above, ${ }^{50}$ as follows: "But how much and how truly would we think, if we didn't think 'in coalescence' with others, with whom we coalesce in truth with each other?"

48 The model of copyright as an ideal "contract" between author and public (or between author and society at large, as is commonly stated) is implicitly grounded in this misconception of the act of speaking in public. Hence the idea that copyright could be ultimately replaced by private contracting. For an insightful analysis of this issue, see Niva Elkin-Koren, What Contracts Can't Do: The Limits of Private Ordering in Facilitating a Creative Commons, 74 FORDHAM L. REV. 101 (2005).

49 "Coalesce" is meant here in its proper etymological sense, as cum alescere "nourishing, making grow together." The noun "coalescence" denotes a unity whereby every coalescing element contributes on its own to a common growing. The Oxford Dictionary reports some enlightening uses of this verb, such as: to give birth to a new stance ("the Conquerors and Conquered coalesced into one and the same People," anon. 1692), to lift to a superior unity ("[t]o find the truth in which Religion and Science coalesce," Spencer 1862), to blend elements which tend to confuse ("both of them should coalesce into one person, but without confounding them together," Goodwin 1679), and even to unite in a manner that sorts out confusion (to coalesce "the apparent bulk of the nation in one common interest"; anon. 1790). See the entry for "Coalesce": Coalesce, in OXFORD ENGLISH DICTIONARY, supra note 46.

50 See supra note 24 and accompanying text. 
The term coalescence appears particularly suitable to denote a human togetherness where the furtherance of truth is the primary end. It differs from other neighboring terms such as "community" or "society," where what is at stake is the need for dealing with each other or the necessity to engage in a reciprocal exchange of "personal" self-expressions. ${ }^{51}$ In coalescence, by contrast, men are bound only by the fact that they share a common responsibility towards truth itself.

This form of togetherness has three traits that must be considered. First, coalescence denotes a mode of human existence which belongs to men as such, independently of whether each person is actually together with others or not. So, an act of speaking publicly in one's own name is per se a coalescing act, prior to reaching the public in any effective way. Through publication, the author's own word becomes properly what already is $a b$ origine, namely a word addressed to other human beings aimed at the elucidation of truth.

Second, coalescence is a togetherness where everyone is expected to "carry his own weight." As a matter of fact, thinking is one of the few "activities" that no man can outsource, so to speak, to others. ${ }^{52}$ In our discourse, this fact is intimately related to the requirement that an act of public address must be in one's own name in order to be the proper subject matter of copyright. ${ }^{53} \mathrm{~A}$ thinking coalescence arises only when a speech in one's own name encounters an audience which is, in turn, in someone's own name. ${ }^{54}$

Third, coalescence is such that it generates other coalescences. Any public address is likely to engender further public addresses. As a matter of fact, the

51 On the concept of "society," Hannah Arendt observes that it underlies a conception of humanity which is fundamentally not free. The Latin word societas (which has no equivalence in the Greek world) indicated an alliance or an agreement finalized to a given end, such as the government (societas regni), crime (societas sceleris) or commerce (simply societas). It was not until the modern age that the adjective "social" started denoting the human condition as such. HANNAH ARENDT, THE Human CONDITION 23 (Univ. of Chi. Press 2d ed. 1998) (1958).

52 Kant addresses this issue in the essay What Is Enlightenment?, where he presents as a maxim of a humankind in a "state of tutelage" the following sentence: "I need not think, if I can only pay; others will easily take this tedious job over for me." Kant, supra note 30 , at 33 . In a way, what we nowadays call the "information society" is the organization on a global scale of a permanent nonstop process of outsourcing of thinking. (For a critical discussion see Borghi, supra note 30.)

53 See sources cited supra notes 30-32 and accompanying text.

54 For each act of speaking in one's own name there is a corresponding act of listening and replying in one's own name. Hence what Abraham Drassinower terms a "dialogue." Drassinower, supra note 1 . 
act of speaking publicly in one's own name not only does not prevent, but actually encourages others to speak in their own name on the same subject. ${ }^{55}$ Truth is never obtained once and for all. Even the most enlightening truth is fated to be outweighed by untruth if it is no longer furthered and clarified. ${ }^{56}$ Thus no act of thinking can be conclusive, and truth can never become a property of a single instance - be it of a single human being or a plurality thereof, such as a majority. ${ }^{57}$ Coalescence is a human togetherness where the furtherance of truth has unconditional priority over the ownership thereof.

We may conclude that copyright is neither (just) about "the author" as such nor (just) about "the public" as such, but is primarily about the author-public coalescence. The copyright sphere is the thinking coalescence that each act of speaking publicly in one's own name generates.

This insight may permit us to distinguish the specific nature of copyright. To do this, the next step is to undertake a summary comparison between copyright and the two rights that have traditionally been associated with it, namely patents and trademarks.

\section{Copyright and Its "Fellow Rights" - Patents AND TRADEMARKS}

Copyright, patents and trademarks are commonly lumped under the umbrella term intellectual property rights. It is also common, at least in legal scholarship, to dislike such an amalgamation and to consider it objectionable in many respects. Many scholars would agree with the following statement of Richard Stallman: "[I]f you want to think clearly about the issues raised by patents, or copyrights, or trademarks, the first step is to forget the idea of lumping them together, and treat them as separate topics." ${ }^{58}$

It is well known that the construct intellectual property, although old enough to be deserving of a right of citizenship in the legal vocabulary, ${ }^{59}$ was not used as a general tag for the said triad until very recently. ${ }^{60}$ Moreover, it

55 The doctrine of fair dealing for purposes of criticism or review is based on this trait of the coalescence. $C f$. id. at 1004-05.

56 See source cited supra note 41 and accompanying text.

57 To be sure, truth decided by a majority opinion is an abhorrence.

58 Richard Stallman, Did You Say "Intellectual Property"? It's a Seductive Mirage, http://www.gnu.org/philosophy/not-ipr.html (last visited Feb. 28, 2010).

$59 C f$. Brad Sherman \& Lionel Bently, The Making of Modern Intellectual PROPERTY (1999).

60 The construct did not enter popular usage until the late 1960s, after the foundation of WIPO. Mark A. Lemley, Property, Intellectual Property, and Free Riding, 83 
can be observed that the subject of copyright has less to do with that of patents or trademarks than with other areas of law. Should one conclude that gathering copyright, patents and trademarks into a single category is purely arbitrary; or (which is the same) that it is merely the result of historical contingency?

To answer this question we must carefully distinguish two issues that tend to be confused, with fatal consequences. The one is the ground, if any, for considering copyright, patents and trademarks as parts of a common body of law. The other is whether such an alleged commonality is sufficiently grasped by the notion of intellectual property. These two issues are in fact distinct: it might be the case that copyright, patents and trademarks do actually share a common ground, but that such a common ground does not — or does not primarily - consist in the fact that these are all property-like rights upon certain given "intellectual" (i.e., non-physical) entities. In other words, copyright, patents and trademarks may have in common a more substantial trait than that which is designated by the passe-partout notion of intellectual property.

In the following I argue that these three rights do actually share a common ground, and hence the grouping of copyright, patents and trademarks into a triad is not arbitrary or merely contingent. At the same time, however, the designation of the triad as intellectual property is of no guidance in such an analysis, and it is possibly inappropriate.

There is no doubt that the concept of "property" itself would go against the grain of the coalescing character of copyright, such as we have tried to establish it so far. ${ }^{61}$ Yet the problem with the term "intellectual property" lies more in the former element of the construct (intellectual) than in the more famous - latter (property). ${ }^{62}$ The idea that a category of rights can be construed on the basis of their relying on, and consisting of, an allegedly human "mental" activity, embracing any kind of operation - such as creating an original expression, disclosing a new and non-obvious idea and representing

TEX. L. REV. 1031, 1033 n.4 (2005). For the use of "intellectual property" in British jurisprudence see David Vaver, Intellectual Property: The State of the Art, $116 \mathrm{LAW}$ Q. REV. 621 (2000).

61 This does not mean that dealing with copyright subject matter as a form of property is to be excluded in principle, but only that this dealing does not correspond with the sense of copyright proposed here. As we shall see, infra notes 61-68 and accompanying text, both patents and trademarks have a coalescing character, although of different meaning and scope than that of copyright.

62 Not surprisingly, criticisms of the "intellectual property" construct focus almost exclusively on the idea of property. See, e.g., RonAn DEAZley, RETHINKING COPYRIGHT: HISTORY, THEORY, LANGUAGE 139-43 (2006). 
a distinctive identity — is particularly misleading. The all-embracing idea of "intellectual" activity as such is misleading, since it leads to confusion. The specificity of copyright is fated to be obliterated.

The trait that copyright shares with patents and trademarks is a specific relation to truth. In what follows, I shall develop this point only to a limited extent, in order to help clarify the specificity of copyright. ${ }^{63}$

\section{A. Copyright and Patents}

In Section II.B. we characterized copyright as the right that protects a thinking coalescence, i.e., a human togetherness aimed at truth. The word "reliance" has provided us with a clearer understanding of what truth is. In particular, we have noticed that truth needs (a coalescing) mankind in order to $b e$, and that truth simply does not subsist failing a thinking coalescence. In this understanding, copyright is a peculiar manner of being in the truth, a manner whereby truth itself is explicitly taken as an issue or, better, the issue. This occurs in many ways and not only when the author openly puts a rational or factual truth into question. The act itself of speaking publicly in one's own name is a "coalescing act," whereby the author, so to speak, submits his own words to a thinking coalescence.

Yet this is a specific manner of being in the truth. Not all likely ways of being in the truth are such that truth itself is taken as the issue. What characterizes a thinking coalescence is precisely the fact of being in the truth in a manner that takes truth as (the main) issue. A thinking coalescence occurs whenever the elucidation of truth is the primary end, in all the ways in which this elucidation can be furthered: inquiring, questioning, challenging, grounding, drawing attention to, and so forth. It is a being in the truth for truth's sake.

Now, being in the truth for truth's sake is not the only manner in which men are in the truth. On the contrary, it is relatively rare. Truth rarely needs

63 Drassinower has provided many insights for the summary analysis which I develop in what follows. Although Drassinower doesn't focus on the relation to truth as the key element in the comparison between the three rights, he identifies each of them as expressing primarily a relation, namely, a relation "between persons and objects" in the case of patents and an "interpersonal relation" in the case of both trademarks and copyright. While with trademarks the relation implies a "unilateral communication," in the case of copyright the relation takes the full shape of a dialogue. In Drassinower's reading, the specificity of copyright stems from the very nature of its subject matter as public address. Drassinower, supra note 8. 
to be explicitly interrogated. In the normal course of life, men simply rely on truth without taking it as an issue.

Since truth is "the ground on which we stand,"64 the most common attitude towards truth is simply to rely on it. What is at stake in such reliance is not truth as such, but rather the fact that truth enables men to rely and build upon it. Relation to other human beings is still pivotal to this way of being in the truth, but this relation is now mediated by relations to things, namely artifacts. Here the relation to truth consists of interpreting a given reliance, rather than questioning that reliance. When a new manner of interpreting a given reliance comes to light, then we have what is commonly called an invention.

Thus there is a possible relationship between the subject matter of copyright and that of patent. While the subject matter of copyright is an act of public address for truth's sake, the subject matter of patent is an act of interpreting a given truth. A patent, as a public document, is also a speech addressed to the public. However, in the case of patents the coalescence that arises through the speaker-addressee relation is not directly achieved by the fact itself of addressing an issue publicly - as in the case of copyright. Here the coalescence is engendered by virtue of a common reference to what is being disclosed in the public address, that is to say, in the patent. A patent is not primarily an (original) author's own word aimed at truth as such, but a (new and unobvious) way of interpreting a given reliance. It is the novelty and non-obviousness of this interpretative act that justifies a temporary right to exclude other coalescing parties from the use of the act which is disclosed to them. Two points should be mentioned.

First, in order to have an invention (and hence a patent) a reliance must be given previously. In more classical terms: given a technical problem, the invention discloses a (new and non-obvious) way to solve it. The invention is a disclosure of a manner to solve a given problem. It does not disclose a problem as such.

Second, and consequently, the patent as a written document is a speech to the public in the inventor's own name.${ }^{65}$ Here, however, the inventor-public relationship is not - at least not primarily — a thinking coalescence. Instead it is a working coalescence. What is relevant here is to work the invention, as a peculiar manner of interpreting a given reliance, and not to think the reliance as such. ${ }^{66}$

64 See ARENDT, supra note 36, at 259.

65 On patent as public discourse, see Mario Biagioli, Patent Republic: Representing Inventions, Constructing Rights and Authors, 73 Soc. RES. 1129, 1132 (2006).

66 This point is made clear, for instance, by the fact that the patent's addressee is always 


\section{B. Copyright and Trademark}

Among the so-called intellectual property rights, trademark is perhaps the one to which the attribute of "property" is least pertinent. ${ }^{67}$

The proper subject matter of a trademark is neither primarily an act of speaking publicly in one's own name nor an act of disclosing a manner of interpreting a given reliance. What is relevant with a trademark is neither that something is publicly addressed, nor what is being addressed. Trademark is concerned only with the fact that "it" is being addressed by someone, and not by others. Trademark has to do with pure selves, or, in classical terms, with "distinctive identities," where the distinctiveness stands for the capacity of distinguishing a thing (good or product) from other things. Distinctiveness is the aptitude of an identity to be a true identity, namely: to be itself and not anything else. ${ }^{68}$ What is relevant is the likelihood of differentiating "it" from others, no matter how such difference is obtained. Here, again, we have a relation to others which is mediated by things, where things however are not seen primarily as objects to work with (as in patents), but rather as goods to trade with. In such trading, the primary concern is to differentiate one's identity from the others', one "self" from all other selves. The relation to selves is prior to any relation to others through things. Thus, in trademark as well there is a coalescing character, insofar as a trademark is addressed to a trading coalescence. ${ }^{69}$

A trading coalescence needs to rely on a given reliance too, for instance in the form of goodwill attached to a self. What is needed here is that this reliance should be distinguishable as such, and to this end it must be represented by visible signs. A trademark is a representation of a given reliance.

a skilled addressee, and this means: a human being in his capacity of interpreting reliance, and namely a given specific reliance (skilled in the art).

67 See Lionel Bently, Communication to Thing: Historical Aspects to the Conceptualisation of Trade Marks as Property, in TRADEMARK LAW AND THEORY: A HANDBOOK OF CONTEMPORARY RESEARCH 3 (Graeme Dinwoodie \& Mark Janis eds., 2008).

68 The classical trademark test for distinctiveness is the likelihood of confusion.

69 The English noun and verb "trade" is much richer than the common association with "buying and selling" would suggest. "Trade" is cognate with "tread" and has originally the sense of "to tread a path." A "trade" is a path, a track, a course of action: one's own habitual way of being - hence the sense of one's own business. Compare the entries for "Trade": Trade, in Online Etymology Dictionary, supra note 46 (search "Trade"; then follow hyperlink) and Trade, in OxFORD ENGLISH DICTIONARY supra note 46. 
To summarize, in all three "fellow rights" there is a reference to truth, which implies a coalescing character. However, the relation to truth has a different tone in each of the three elements of the triad: ${ }^{70}$

Copyright $\rightarrow \quad \begin{aligned} & \text { relation to others } \\ & \text { (thinking coalescence) }\end{aligned} \rightarrow \begin{aligned} & \text { furthering and maintaining } \\ & \text { (elucidating) truth }\end{aligned}$
Patent $\rightarrow \quad \begin{aligned} & \text { relation to things } \\ & \text { (working coalescence) }\end{aligned}$
Trademark $\rightarrow \quad \begin{aligned} & \text { relation to selves } \\ & (\text { trading coalescence) }\end{aligned}$

\section{Conclusion: Provisional Remarks on the Primacy of COPYRIGHT}

Truth as reliance is an instance at stake in all the three main directions of human existence that we have singled out, namely towards oneself, towards things, and towards other human beings. The whole of these three directions is what we call a world. ${ }^{71}$ When we relate to things we rely on reliance; when we relate to ourselves we need to represent reliance; and when we relate to others we elucidate reliance. ${ }^{72}$ In all these relations, and not only in the last one, man is coalescing with other men. The tone of this human coalescence is different in each of the three kinds of relation, and accordingly we find what

70 Further extensive analysis would be needed to address the issue of how the coalescing character of copyright, patents and trademarks determines their respective scope, and why, for instance, a working coalescence entails a set of rights which is different in rationale and scope from that which is required by a thinking coalescence.

71 On this issue, which cannot be developed here, see ARENDT, supra note 51, at 167-74.

72 Certainly, these relations are in turn intimately related to one another. One cannot relate to other human beings without, at the same time, relating to oneself and to things "in between" oneself and others. For instance, when an author addresses a speech to the public, the resulting coalescence must necessarily include a relation to "what" is being addressed in the speech (thing) and to "who" is addressing the speech (self). The distinction between the three kinds of relations, or directions of human existence, is purely analytical. Therefore we can say that copyright is primarily (but not exclusively) about relation to others, but the same cannot be said for patent and trademark with respect to things and selves. 
we have termed a working, trading and thinking coalescence, respectively. All these forms are related to each other, and they are equal in rank.

Nevertheless, the thinking coalescence, which articulates the relation of human existence to others, has a singular preeminence over the two other coalescences and their respective underlying relations. In a way, truth is first and foremost what men experience in thinking, and since, as has been shown, it belongs to the very nature of thinking to be carried out in common with others, it follows that truth is primarily apprehended by acts of speaking publicly in one's own name. Such preeminence is not a priority in the sense that the other ways of experiencing truth depend on or are subordinated to acts of thinking. As a matter of fact, affairs of men, their working and trading, can run perfectly without the assistance of thinking. What thinking provides is just a gratuitous and perhaps unnecessary pivot. To use a pertinent Latin expression, we may say that what we have termed a "thinking coalescence" is a primum inter pares in the triad of human coalescences: it is primum, since it is pivotal to any human coalescence as such, but inter pares, since all other forms have equal rank and dignity.

Accordingly, copyright is primum among its peer fellow rights. Nowhere is this preeminence clearer than in the institutions that define the permitted acts under copyright law, namely limitations and exceptions, the British doctrine of fair dealing and its American counterpart, fair use. ${ }^{73}$ It is disputed whether these institutions should be interpreted as restrictions to the author's rights, that can be applied only negatively as a defense against infringement liability, or whether they define true and proper users' rights, that can be positively asserted by any author's counterpart. ${ }^{74}$ The reference to the truth as the proper "what-about" of copyright may suggest that copyright is neither author's nor users', but just, if I may say so, coalescence's right. As far as the fair dealing defense is concerned, it might be argued that the "fairness" is nothing but the perfection of reciprocal acts aimed at furthering truth -

73 In a broader sense, permitted acts are also defined by institutions such as the idea/expression dichotomy, the "substantial part" requirement, the private copying limitation, the rule of exhaustion (or "first sale" doctrine) and the limited time of protection. All these institutions - whose analysis lies beyond the scope of this Article - have been developed over time from a single concept, namely defining the boundaries of infringement liability. For an overview, see Melissa De Zwart, A Historical Analysis of the Birth of Fair Dealing and Fair Use: Lessons for the Digital Age, 1 INT'L. PROP. Q. 60 (2007).

74 Lyman Ray Patterson \& Stanley W. LindBerg, The NATURE of Copyright: A LAW OF USER's RightS (1991); Jessica Litman, The Exclusive Right to Read, 13 CARDOZO ARTS \& ENT. L.J. 29 (1999). 
acts which, so to speak, resonate with and enlighten each other, since it is in the very nature of copyright to withstand coalescence. 